\title{
Effectiveness of various types and norms of fertilizers in increasing the productivity of cultivated crops and the fertility of gray forest soil in the Pre-Kama Area of Tatarstan
}

\author{
Rafil C. Shakirov ${ }^{1}$, Zakirzhan M. Bikhmuhammetov ${ }^{1}$, and Fidail F. Khisamiev ${ }^{2}$ \\ ${ }^{1}$ Saby Agrarian College, 422060 Bogatye Saby urban-type settlement, Saby municipal district, Republic of Tatarstan, Russia \\ ${ }^{2}$ LLC "Iulbat" agricultural company, 422077 Iulbat village, Saby district, Republic of Tatarstan, Russia
}

\begin{abstract}
The article discusses the effectiveness of various types and norms of organic fertilizers in improving soil fertility, productivity and crop production quality, as well as crop rotation productivity in a comparative aspect with the estimated norms of mineral fertilizers for obtaining the planned yield. Various norms of thermally dried granulated chicken manure were studied, its suitability as an environmentally safe complex organic fertilizer and its effectiveness in increasing yields, produce quality, soil fertility and crop rotation productivity compared with traditional manure, buckwheat green manure crop, mineral fertilizers and natural nutritional background were established. The economic efficiency of the use of various types of fertilizers in crop rotation is determined and its increase to a profitability level of 74-222\% depending on the type and norms of fertilizers is established.
\end{abstract}

\section{Introduction}

The modern system of agriculture should be based on the reproduction of soil fertility, energy and resource conservation and environmental balance. This requires the skillful use of local resources and the development of methodical approaches and techniques to optimize destabilizing and stabilizing performance factors.

One of the destabilizing factors is soil degradation and loss of humus. Analysis shows that the growth of crop yields not only in Tatarstan, but also in the Russian Federation is accompanied by the processes of accelerated degradation of the soil cover. Thus, in the Republic of Tatarstan, the annual loss of humus is $1100-1800 \mathrm{~kg} / \mathrm{ha}$, and to replenish this loss it is required to add at least $10.6 \mathrm{t} / \mathrm{ha}$ of organic fertilizers annually, for expanded reproduction of the soil fertility - more than $12 \mathrm{t} /$ ha of arable land per year. Unfortunately, in the republic the application of organic fertilizers is only $1.2-1.5 \mathrm{t} / \mathrm{ha}$ of crops.

As a result, the negative humus balance is $0.3 \mathrm{t} / \mathrm{ha}$ of crops [1]. Therefore, it is necessary to effectively use all types of organic fertilizers (manure, straw, green manure, bird droppings, etc.), which are the most important factors of resource conservation and reproduction of soil fertility, especially in conditions of the high cost of mineral fertilizers.

However, not all local organic fertilizers have been studied enough. Among them, bird droppings remain little studied. This is due to the fact that small farms were previously engaged in poultry farming and the yield of bird droppings was insignificant. In connection with the construction of modern poultry farms, industrial poultry farming is currently operating and the volumes of bird droppings have become very large, which poses a great danger to the ecology of the environment. Therefore, the study of effective methods of processing and using bird droppings as organic fertilizers in agriculture has become relevant and in demand.

The issue of using bird droppings as a valuable organic fertilizer is not new in itself. A number of researchers note that bird droppings are quite suitable as raw materials for use as organic fertilizers in agriculture [4].

Bird droppings are rich in nutrients, which are in an accessible form for plants, quickly dissolve in water, and are easily digested. In terms of the effect on the crop in the first year of application, bird droppings are close to mineral fertilizers. Due to the high concentration of organic components and their gradual release, bird droppings affect the yield in the next 2-3 years i.e. have aftereffect [2]. At the same time, the efficiency of using heat-treated chicken droppings in increasing soil fertility and crop rotation productivity has not been studied enough, and in the conditions of gray forest soil in the Pre-Kama area of Tatarstan has not been studied at all.

Green manure crops are of great importance in the reproduction of soil fertility and increasing crop yields. D.N. Prianishnikov wrote about the importance of these crops: "In combination with manure and other organic fertilizers, as well as mineral fertilizers, green manure as one of the elements of the fertilizer system should become a very powerful means of raising crops and increasing soil fertility" [6].

The issues of using plants for green manure have been thoroughly studied more than once. But as the

* Corresponding author: faik1948@ mail.ru 
intensification of agricultural processes, especially biological ones, grows and the problem of preserving and increasing soil fertility becomes more acute, the interests of the cause make us turn again to this universally accessible, highly efficient type of organic fertilizers, selecting effective green manure crops, revealing their new qualities, new properties and mechanisms of effect on the soil.

In general, for the effective use of various types of fertilizers, it is necessary to study their fertilizing properties, the effect on the agrochemical, agrophysical parameters of the soil and the productivity of the arable land. D.N. Prianishnikov pointed out on this issue: "In order to evaluate the fertilizing value of a substance, to be able to regulate plant nutrition in the field, you need to know not only the needs of plants at all stages of their development, but also need to be familiar with a number of soil properties and physical, chemical and biological processes undergoing in it" [5].

Given the relevance of this guidance, in our experiments on studying the effectiveness of various types and norms of fertilizers, special attention was paid to elucidating the effect of the studied fertilizers on water-food regimes, biological activity and toxicity of the soil, which ultimately determined the effective methods of their use.

\section{Research Program and Methodology}

The studies were carried out in 2016-2018 on the experimental field of the Saby Agrarian College, located on the territory of the "Iulbat" agricultural LLC of the Saby municipal district of the Republic of Tatarstan (the Pre-Kama zone).

The soil is the gray forest one, with a granulometric composition of heavy loam.

The initial agrochemical parameters of the experimental field were the following: humus content, according to I.V. Tyurin $-3.2 \%$, alkaline hydrolyzable nitrogen - 80-90 mg/kg, $\mathrm{P}_{2} \mathrm{O}_{5}-150-200, \mathrm{~K}_{2} \mathrm{O}-100-110$ $\mathrm{mg} / \mathrm{kg}, \mathrm{pH}$ of arable layer salts - 4.6.

The tillage system with following nine-field crop rotation was studied: 1) annual grasses (feed mixture); 2) winter rye; 3) spring wheat; 4) corn; 5) spring wheat; 6) peas; 7) winter rye; 8) corn; 9) spring wheat.

The experiments were carried out on a three-fold surface with sequential placement of plots in the tillage sequence of the indicated crop rotation. The size of the plots was $10 * 25 \mathrm{~m}$, the area was 250 square meters. $\mathrm{m}$. The technology of cultivating rotation crops was typical for the Pre-Kama zone of the Republic of Tatarstan.

The objects of study were spring wheat (cultivar Tulaikovskaya 108) and corn (cultivar ROSS 199). We studied the effectiveness and aftereffect of traditional manure, green manure and various norms of heat-treated chicken manure compared with the estimated norms of mineral fertilizers for receiving $3,4,5 \mathrm{t} / \mathrm{ha}$ of spring wheat and 30, 40, $50 \mathrm{t} / \mathrm{ha}$ of green corn. The complete outline of the experiment is presented in the tables below.
Weather conditions during the years of the experiment were different; in 2016 and 2017 they were not entirely favorable. In 2016 precipitation in May was $50 \%$ of the norm, with an average daily air temperature of $16.3 \%$, above the norm, which negatively affected the tillering of spring wheat. In the first decade of June precipitation ( $32 \mathrm{~mm}$, i.e. $160 \%$ of the norm) and the normal average daily air temperature (14.6 degrees) favored the passage of tillering and booting phases of plants.

The optimum temperature and moderate precipitation in the second and third decades of June contributed to the good growth and development of wheat plants. As a result, $13 \mathrm{~mm}$ of precipitation fell (the norm is $59 \mathrm{~mm}$ ), with the average daily air temperature of 21.9 degrees (2.4 degrees higher than the norm), which led to accelerated ripening of wheat, the relatively dry and hot August weather made high-quality harvesting possible.

In the initial period (May) of the growing season of 2017 , the average daily air temperature was 2.8 degrees below the norm, the rainfall was $74 \%$ of the norm. The lowered air temperature adversely affected the germination of corn seeds and the emergence of even sprouts. Cool weather continued in the month of June (average monthly temperature was below the norm by 2 degrees), which delayed the growth and development of corn.

Abundant monthly precipitation (163\% of the norm) and an increase of the average daily air temperature in the second and third decades of July to 21-22 degrees improved the situation and the growth rate of corn increased. Favorable conditions were created in August and early September, which led to a good formation of ears of corn and the accumulation of the green weight of top.

Weather conditions in the growing season of 2018 were generally favorable. But spring was cold and rainy. In the first decade of May, cool weather with precipitation lingered, the soil temperature in the $10 \mathrm{~cm}$ layer was only 8 degrees, which delayed the time for sowing wheat. In the second decade of May, the average daily air temperature increased to 16.3 degrees (3.3 degrees higher than the norm), there was no precipitation, which made high-quality sowing possible.

Precipitation ( $125 \%$ of the norm) in the first ten days of June and the average daily air temperature close to a long-term norm (12.8 degrees) favorably affected the tillering of the plants; precipitations in the second and third decades of precipitation also contributed to the good growth and development of wheat. In July and August, weather conditions were favorable for grain swelling and ripening. In the first and second decades of August, precipitation was less than the norm, the average daily temperature was above the norm, contributing to the full ripening of grain and quality harvesting.

\section{Results}

In the forest-steppe zone, field crop cultivation, mainly of grains, is rather well developed, and the main branches of animal husbandry are cattle raising, pig 
breeding, poultry farming, and sheep breeding. The total number of horses is significant. In Tatarstan, there are 1 million 252 thousand basic cattle units per 3.4 million hectares of arable land. At the same time, about 12-15 million tons of manure are accumulated per year. It contains about 55-70 thousand tons of nitrogen, $30-35$ thousand tons of $\mathrm{P}_{2} \mathrm{O}_{5}, 60-80$ thousand tons of $\mathrm{K}_{2} \mathrm{O}$, 50-60 thousand tons of $\mathrm{CaO}$, a large number of trace elements. The amount of NPK per 1 ha of arable land is more than $40-50 \mathrm{~kg}$.

The number of birds in the republic is 14.5 million. The annual output of bird droppings reaches more than 1.5 million tons. Fertilizing qualities of bird droppings, in particular chicken droppings, are superior to manure and not inferior to mineral fertilizers in terms of the speed of action. However, due to the lack of knowledge of effective methods of application, this valuable fertilizer does not find rational use in agriculture, and its accumulated large masses are polluting the environment.

Admittedly, green manure crops play an important role in replenishing the soil's organic matter and improving its humus content. They are considered to be a cheap, generally available source of replenishing soil organic matter, and environmentally safe and economically efficient organic fertilizer. According to our data, the cultivation of green manure and its incorporation into the soil, especially in far-off areas, is 2 times cheaper than the production, transportation and application of an equivalent amount of manure and 6 times cheaper compared to industrial fertilizers. In terms of agronomic efficiency, they are close to strawbased manure (6).

Recently, among large Chinese farms (in Ghana), , green manure crops in combination with chicken droppings have been used in order to improve soil fertility and good results have been achieved in increasing the carbon and nitrogen content in the soil and improving their $\mathrm{C}: \mathrm{N}$ ratio (3).

Legumes (lupine, seradella, melilot, peas, vetch, etc.) are most often used as green manure crops. Nonleguminous plants (mustard, rape, winter cress, buckwheat) are also used. However, most of these crops are primarily used for food at farms. Thus, only $1.1 \%$ of arable land is occupied by green-manured fallow in the Republic of Tatarstan. Therefore, it is necessary to skillfully select the species composition of the cultivated green manure crops. We have carried out all-round work to study the effectiveness of a large group of green manure plants.

Among the studied plants for sideration, along with legumes, buckwheat varieties "Batyr" and "Cheremshanka" provide good results, having high energy of initial growth. They suppress weeds, clear the soil of diseases. The buckwheat root system releases phytoncides that destroy pathogenic microorganisms, causing root rot and other diseases, in the soil. The seeding rate is $60-70 \mathrm{~kg} / \mathrm{ha}$, the seeds of the second fraction can be sown. In our experiments, peas and buckwheat provide high yields of dry matter of the top and root and crop residues.

In terms of nutrients (total NPK) entry into the soil with the top yield, buckwheat took the first place among the studied green manure crops. In addition, it is noteworthy that the green mass of buckwheat is not used for livestock feed at farms, but goes completely for sideration. Considering these features, buckwheat was used for comparative screening in experiments to study the effectiveness of various types and norms of fertilizers.

The experiments on this topic were accompanied by numerous related soil and plant analyzes.

One of the limiting factors for obtaining steadily high yields is the lack of moisture, whose accumulation, conservation in the soil and use by plants depends on the structural-aggregate composition of the soil, cultivation techniques and other factors, including fertilizers. Organic fertilizers, as well as chicken droppings, improve the structural-aggregate composition of the soil, loosen it, and the unproductive evaporation of moisture decreases in the loose soil. This is confirmed by the results of our research.

The data in Table 1 on the content of productive moisture in the arable, subsurface and meter soil layers confirm the foregoing and reveal the beneficial effect of fertilizers, especially organic ones. The weighted average, average chronological indicators of productive moisture in all soil layers against the backdrop of organic fertilizers are significantly greater compared to the control natural background. The number of these indicators, depending on the type of organic fertilizers in the meter layer of soil, varied under the first crop (effect) within $120.4-138.6 \mathrm{~mm}$, with control of $107.1 \mathrm{~mm}$, under the second crop (1st year of aftereffect) within 143.8-170.2 $\mathrm{mm}$ with control of $142 \mathrm{~mm}$, under the third crop (2nd year of aftereffect) within 156.9-177.2 mm with control of $128.2 \mathrm{~mm}$.

A decrease in moisture loss from the soil surface in the variants with the introduction of organic fertilizers was noted, and as a result, its content during the entire growing season was optimal and good. At the same time, in all soil layers from the background of the effect to the background of the second year of aftereffect, the amount of productive moisture has increased dynamically, which is explained by a consistent improvement in the structural-aggregate composition of the soil under the influence of organic fertilizers. I.e., on the background of the second year of the aftereffect, 1-2-3 t/ha of GCM (granulated chicken manure), the content of productive moisture in $0-40 \mathrm{~cm}$ soil layer was $65.8,67.9 ; 75.9 \mathrm{~mm}$ respectively; with $52 \mathrm{~mm}$ on the background of mineral fertilizers with annual application.

The difference in favor of the second year of aftereffect of GCM is 13.8; 15.9; and $23.9 \mathrm{~mm}$, which ensures that with an obligatory calculation an additional yield of $5.52 ; 6.36 ; 9.56 \mathrm{c} / \mathrm{ha}$ is obtained without any fertilizer maintenance, due to improved water resistance of soil aggregates under prolonged exposure to GCM. A similar pattern was observed on the background of the second year of the aftereffect of $42 \mathrm{t} / \mathrm{ha}$ of the strawbased manure in the composition of $3 \mathrm{t} / \mathrm{ha}$ of GCM and $27 \mathrm{t} / \mathrm{ha}$ of buckwheat green manure.

Fertilizers in crop rotation should provide, in combination with complexes of agrotechnical measures, for the preservation and improvement of soil fertility, 
and gaining planned high-quality yields. As data show (Table 2), the weighted average chronological indices of the content of hydrolyzable nitrogen, mobile phosphorus and potassium against the background of the effect and aftereffect of organic fertilizers significantly exceed the background indices without fertilizers (control).

The greatest excess was observed with the use of 2-3 t/ha of GCM and $42 \mathrm{t} / \mathrm{ha}$ of straw-based manure in the composition of $3 \mathrm{t} / \mathrm{ha}$ of GCM. So, as a result of the action of various doses of GCM, the content of hydrolyzable nitrogen in the $0-20 \mathrm{~cm}$ soil layer ranged from 138 to $169 \mathrm{mg} / \mathrm{kg}$ of soil (control was $79.7 \mathrm{mg} / \mathrm{kg}$ ), of mobile phosphorus from 323 to $365 \mathrm{mg} / \mathrm{kg}$ soil (control was $190.8 \mathrm{mg} / \mathrm{kg}$ ), and that of mobile potassium from 194.3 to $280.8 \mathrm{mg} / \mathrm{kg}$ (the control measurement of $97.5 \mathrm{mg} / \mathrm{kg}$ ). With the increase of the amount of GCM applied, the content of these elements in the soil also increased in direct proportion.

Table 1. The content of productive moisture in the soil under grain tillage crop rotation sequence depending on the effect and aftereffect of various forms and norms of organic fertilizers in comparison with the effect of mineral fertilizers and the natural background (weighted average chronological indicators for the growth and development of crops, $\mathrm{mm}$ )

\begin{tabular}{|c|c|c|c|c|c|c|c|c|c|}
\hline \multirow{3}{*}{$\begin{array}{l}\text { Norms and types of } \\
\text { fertilizers }\end{array}$} & \multicolumn{3}{|c|}{ Spring wheat (effect, 2016) } & \multicolumn{3}{|c|}{$\begin{array}{c}\text { Corn }\left(1^{\text {st }} \text { year of aftereffect, }\right. \\
2017)\end{array}$} & \multicolumn{3}{|c|}{$\begin{array}{c}\text { Spring wheat }\left(2^{\text {nd }} \text { year of }\right. \\
\text { aftereffect, 2018) }\end{array}$} \\
\hline & \multicolumn{9}{|c|}{ Soil layer, $\mathrm{cm}$} \\
\hline & $0-20$ & $0-40$ & $0-100$ & $0-20$ & $0-40$ & $0-100$ & $0-20$ & $0-40$ & $0-100$ \\
\hline $\begin{array}{l}\text { Without fertilizers - } \\
\text { control (natural } \\
\text { background) }\end{array}$ & 20.9 & 36.6 & 107 & 26.86 & 49.4 & 142.0 & 28.8 & 53.6 & 128.2 \\
\hline $\begin{array}{l}\text { NPK of mineral fertilizers } \\
\text { to obtain } 4 \text { t/ha of grain } \\
\text { and } 40 \text { t/ha of corn green } \\
\text { mass }\end{array}$ & 22.3 & 39.6 & 119 & 25.9 & 49.4 & 135.0 & 27.8 & 52.0 & 140.5 \\
\hline GCM 1,0 t/ha & 23.7 & 40.6 & 136 & 29.7 & 57.9 & 143.8 & 38 & 65.8 & 156.9 \\
\hline GCM 2,0 t/ha & 23.9 & 44.0 & 137 & 31.2 & 58.3 & 161.6 & 38 & 67.9 & 173.3 \\
\hline GCM 3,0 t/ha & 25 & 43.3 & 139 & 34.4 & 64.9 & 170.2 & 39 & 75.9 & 177.1 \\
\hline $\begin{array}{l}\text { Straw-based manure } \\
42 \mathrm{t} / \mathrm{ha} \text { (in the composition } \\
\text { of } 3 \mathrm{t} / \mathrm{ha} \text { GCM) }\end{array}$ & 21.4 & 39.6 & 126 & 32.7 & 61.4 & 146.2 & 37.5 & 67.6 & 177.2 \\
\hline $\begin{array}{l}\text { Buckwheat green manure } \\
27 \mathrm{t} / \mathrm{ha}\end{array}$ & 21.1 & 38 & 120 & 30.1 & 56.7 & 144.1 & 36.1 & 63.7 & 174.6 \\
\hline
\end{tabular}

Note. Mineral fertilizers were applied every year directly under each crop according to the calculation and balance method for the planned yield.

Table 2. The effect and aftereffect of various forms and norms of organic fertilizers on the content of nutrients in comparison with the effect of mineral fertilizers and the natural background, $\mathrm{mg} / \mathrm{kg}$ of soil (Weighted average chronological indicators for the phases of growth and development of crops in 0-20 cm soil layer)

\begin{tabular}{|c|c|c|c|c|c|c|c|c|c|}
\hline \multirow{2}{*}{$\begin{array}{l}\text { Norms and types of } \\
\text { fertilizers }\end{array}$} & \multicolumn{3}{|c|}{ Spring wheat (effect, 2016) } & \multicolumn{3}{|c|}{$\begin{array}{c}\text { Corn }\left(1^{\text {st }} \text { year of aftereffect, }\right. \\
2017)\end{array}$} & \multicolumn{3}{|c|}{$\begin{array}{l}\text { Spring wheat ( } 2^{\text {nd }} \text { year of } \\
\text { aftereffect, 2018) }\end{array}$} \\
\hline & $\mathrm{Ng}$ & $\mathrm{P} 2 \mathrm{O} 5$ & $\mathrm{~K} 2 \mathrm{O}$ & $\mathrm{Ng}$ & $\mathrm{P} 2 \mathrm{O} 5$ & $\mathrm{~K} 2 \mathrm{O}$ & $\mathrm{Ng}$ & $\mathrm{P} 2 \mathrm{O} 5$ & $\mathrm{~K} 2 \mathrm{O}$ \\
\hline $\begin{array}{l}\text { Without fertilizers - } \\
\text { control (natural } \\
\text { background) }\end{array}$ & 79.7 & 190.8 & 97.5 & 57.0 & 217.0 & 82 & 85.4 & 172 & 83.0 \\
\hline $\begin{array}{l}\text { NPK of mineral } \\
\text { fertilizers to obtain } 4 \\
\text { t/ha of grain and } 40 \\
\text { t/ha of corn green mass }\end{array}$ & 94.3 & 275.0 & 173.3 & 77.3 & 255.8 & 181 & 88.2 & 246 & 159.5 \\
\hline GCM 1,0 t/ha & 138 & 323.0 & 194.3 & 81.3 & 279.0 & 128 & 96.6 & 241 & 135.5 \\
\hline GCM 2,0 t/ha & 144.3 & 343.3 & 234 & 85.8 & 302.3 & 152 & 104.0 & 260 & 186.0 \\
\hline GCM 3,0 t/ha & 169 & 365.0 & 280.8 & 90.3 & 330.0 & 222 & 123.0 & 330 & 293.5 \\
\hline $\begin{array}{l}\text { Straw-based manure } 42 \\
\text { t/ha (in the composition } \\
\text { of } 3 \mathrm{t} / \mathrm{ha} \text { GCM) }\end{array}$ & 95.7 & 295.8 & 162.3 & 75.3 & 257.0 & 115 & 127.0 & 390 & 190.0 \\
\hline $\begin{array}{l}\text { Buckwheat green } \\
\text { manure } 27 \mathrm{t} / \mathrm{ha}\end{array}$ & 94.9 & 300.4 & 198.7 & 71.5 & 263.0 & 150 & 92.8 & 270.6 & 180.1 \\
\hline
\end{tabular}

Their content is much higher than in the options with the annual application of mineral fertilizers with the expectation of receiving $4 \mathrm{t} / \mathrm{ha}$ of grain.

A similar pattern was observed on the backgrounds of the first and second years of the aftereffect of organic fertilizers. In the second year of aftereffect, $3 \mathrm{t} / \mathrm{ha}$ GCM was equated to $42 \mathrm{t} / \mathrm{ha}$ of straw-based manure. In this regard, buckwheat green manure also turned out to equivalent to straw-based manure.

The effect and aftereffect of various forms of fertilizers determined the level of productivity.

The highest average yield for 2016-2018 was obtained on the background of the introduction of $3 \mathrm{t} / \mathrm{ha}$ of GCM and amounted to $5.55 \mathrm{t} / \mathrm{ha}$ of grain-units. With 
the effect, the yield of spring wheat amounted to $4.62 \mathrm{t} / \mathrm{ha}$ of grain-units, the yield of green mass of corn in the first year of aftereffect to $46.1 \mathrm{t} / \mathrm{ha}$ (in terms of grain-units of $7.84 \mathrm{t} / \mathrm{ha}$ of grain-units), in the second year of the aftereffect, the yield of spring wheat was $4.2 \mathrm{t} / \mathrm{ha}$ of grain-units.

The productivity of these crops decreased slightly as the standards for applying GCM to 1-2 t/ha decreased, but it turned out to be at the level of the yield obtained against the background of the annual application of mineral fertilizers on the calculation for the planned yield.
Thus, the yield of spring wheat against the background of mineral fertilizers on the calculation for $4 \mathrm{t} / \mathrm{ha}$ of grain reached 3.43-4.24 t/ha, and under the effect and aftereffects of 1-2 t/ha of GKP $-3.55-4.37 \mathrm{t} / \mathrm{ha}$ of grain-units. The yield of green mass of corn against the background of mineral fertilizers in terms of grain-units amounted to $7.06 \mathrm{t} / \mathrm{ha}$, on the backgrounds of $1-2 \mathrm{t} / \mathrm{ha}$ of GKP amounted to -5.7 and 7.0 t/ha of grain-units respectively (table 3 ).

In terms of effect and aftereffects $42 \mathrm{t} / \mathrm{ha}$ of strawbased manure was almost equivalent to $3 \mathrm{t} / \mathrm{ha}$ of GKP, $27 \mathrm{t} / \mathrm{ha}$ of buckwheat green manure was almost equal to $1 \mathrm{t} / \mathrm{ha}$ of GKP.

Table 3. The effect and aftereffect of various forms of organic fertilizers on the yield of crops of the grain tillage sequence of the grain tillage crop rotation in comparison with the effect of mineral fertilizers and the natural background

\begin{tabular}{|c|c|c|c|c|c|c|}
\hline \multirow{2}{*}{$\begin{array}{l}\text { Norms and types of } \\
\text { fertilizers }\end{array}$} & \multirow{2}{*}{$\begin{array}{l}\text { Effect on } \\
\text { spring } \\
\text { wheat yield, } \\
\text { t/ha grain- } \\
\text { units (2016) }\end{array}$} & \multicolumn{2}{|c|}{$\begin{array}{l}\text { Aftereffect of the } 1^{\text {st }} \text { year on } \\
\text { corn yield (2017) }\end{array}$} & \multirow{2}{*}{$\begin{array}{l}\text { Aftereffect of } \\
\text { the } 2^{\text {nd }} \text { year on } \\
\text { spring wheat } \\
\text { yield, } t / \text { ha grain- } \\
\text { units (2018) } \\
\end{array}$} & \multirow{2}{*}{$\begin{array}{l}\text { Total yield of } \\
\text { 2016-2018, } \\
\text { t/ha grain- } \\
\text { units }\end{array}$} & \multirow{2}{*}{$\begin{array}{c}\text { Total yield } \\
\text { increase as } \\
\text { compared to } \\
\text { control, t/ha grain- } \\
\text { units, 2016-2018 }\end{array}$} \\
\hline & & $\begin{array}{c}\text { Green } \\
\text { mass, } t / h a\end{array}$ & $\begin{array}{l}\text { In grain units, } \\
\text { t/ha }\end{array}$ & & & \\
\hline $\begin{array}{l}\text { Without fertilizers - control } \\
\text { (natural background) }\end{array}$ & 1.95 & 20.9 & 3.55 & 1.90 & 7.40 & ( \\
\hline $\begin{array}{l}\text { NPK of mineral fertilizers } \\
\text { to obtain } 4 \text { t/ha of grain and } \\
40 \text { t/ha of corn green mass }\end{array}$ & 4.24 & 41.5 & 7.06 & 3.43 & 14.73 & 7.33 \\
\hline GCM 1,0 t/ha & 4.22 & 33.5 & 5.7 & 3.55 & 13.47 & 6.07 \\
\hline GCM 2,0 t/ha & 4.37 & 41.2 & 7.0 & 3.88 & 15.25 & 7.85 \\
\hline GCM 3,0 t/ha & 4.62 & 46.1 & 7.84 & 4.20 & 16.66 & 9.26 \\
\hline $\begin{array}{l}\text { Straw-based manure } 42 \mathrm{t} / \mathrm{ha} \\
\text { (in the composition of } \\
3 \mathrm{t} / \mathrm{ha} \text { GCM) }\end{array}$ & 3.93 & 44.9 & 7.63 & 4.05 & 15.61 & 8.21 \\
\hline $\begin{array}{l}\text { Buckwheat green manure } \\
27 \mathrm{t} / \mathrm{ha}\end{array}$ & 3.72 & 35.0 & 5.95 & 3.60 & 13.27 & 5.87 \\
\hline
\end{tabular}

Least significant difference $0,5 \mathrm{t} / \mathrm{ha}$

$0,10 \quad 0,78$

0,116

Note: N 153 P 91 K 102 - for spring wheat per 4 t/ha of grain, 2016

N107 K108 - for corn to receive 40 t/ha of green mass, 2017

N 145 P 86 K 95 - for spring wheat per 4 t/ha of grain, 2018

Table 4. Economic efficiency of applying various forms and norms of organic fertilizers in comparison with mineral fertilizers and the natural background

\begin{tabular}{|l|c|c|c|c|c|c|}
\hline \multicolumn{1}{|c|}{ Norms and types of fertilizers } & $\begin{array}{c}\text { Average yield in } \\
\text { 2016-2018, t/ha, } \\
\text { grain-units }\end{array}$ & $\begin{array}{c}\text { Total gross } \\
\text { product, } \\
\text { rubles/ha }\end{array}$ & $\begin{array}{c}\text { Expenditur } \\
\text { es, } \\
\text { rubles/ha }\end{array}$ & $\begin{array}{c}\text { Cost price of } \\
\text { 1 centner of } \\
\text { grain-units, } \\
\text { rubles }\end{array}$ & $\begin{array}{c}\text { Net income, } \\
\text { rubles/ha }\end{array}$ & $\begin{array}{c}\text { Profitability } \\
\%\end{array}$ \\
\hline $\begin{array}{l}\text { Without fertilizers - control } \\
\text { (natural background) }\end{array}$ & 2.47 & 19760 & 7800 & 315.79 & 11960 & 153.3 \\
\hline $\begin{array}{l}\text { NPK of mineral fertilizers to obtain 4 } \\
\text { t/ha of grain and 40 t/ha of corn green } \\
\text { mass }\end{array}$ & 4.91 & 39280 & 23732.4 & 458.25 & 15547.6 & 65.5 \\
\hline GCM 1,0 t/ha & 4.49 & 35920 & 11133.3 & 247.95 & 24786.7 & 222.6 \\
\hline GCM 2,0 t/ha & 5.08 & 40640 & 14466.3 & 284.77 & 26173.7 & 180.9 \\
\hline GCM 3,0 t/ha & 5.55 & 44400 & 17799.9 & 320.72 & 26600.1 & 149.4 \\
\hline $\begin{array}{l}\text { Straw-based manure 42 t/ha (in the } \\
\text { composition of 3 t/ha GCM) }\end{array}$ & 5.2 & 41600 & 24800 & 476.92 & 16800 & 67.74 \\
\hline Buckwheat green manure 27 t/ha & 4.42 & 35360 & 10950 & 247.74 & 24410 & 222.92 \\
\hline
\end{tabular}

Under the direct effect of various GCM norms and their aftereffects of the first and second years, the productivity of the grain tillage sequence of the grain tillage crop rotation increased by $82-125 \%$ (6.07-9.26 t/ha of grain-units), with the increase in the application rates of GKP, the crop rotation productivity increased respectively. Due to effect and aftereffect of $42 \mathrm{t} / \mathrm{ha}$ of straw-based manure, the productivity of the crop rotation sequnece increased by $110.95 \%, 27 \mathrm{t} / \mathrm{ha}$ and that of buckwheat green manure - by $79.32 \%$ relative to control (natural background).

With the annual application of high doses of mineral fertilizers, based on the planned yield, the productivity of the crop rotation sequence increased by $99 \%$ compared to control without fertilizers. 
Calculations of economic efficiency show that with the use of organic fertilizers, taking into account their effect and aftereffect, the cost of production decreases, profitability increases compared to the annual application of mineral fertilizers for the planned yield (table 4). Thus, the cost of one centner of grain-units amounted to 458.25 rubles against the background of mineral fertilizers, and with the addition of $1-2-3 \mathrm{t} / \mathrm{ha}$ of GCM and 27 t/ha of buckwheat green manure, 247.45-284.77-320.72 rubles and 247.74 rubles respectively. At the same time, the profitability of production against the background of mineral fertilizers amounted to $65.5 \%$. With the use of GCM, depending on the dose, the profitability increased to the level of 149.4-226.6\%, with the use of buckwheat green manure - to $222.9 \%$.

The application of $42 \mathrm{t} / \mathrm{ha}$ of straw-based manure (in the composition of $3 \mathrm{t} / \mathrm{ha}$ of GCM) once in the crop rotation sequence is more effective (profitability $67.74 \%$ ) than the annual application of high doses of mineral fertilizers for each crop to obtain the planned yield.

Against the background without fertilizers, the profitability is high $-153.3 \%$, the cost price is acceptable -315.79 rubles/centner of grain-units, with an average yield of 2.47 tons/ha of grain-units for 2016-2018. These are good results for gray forest soils.

However, the systematic cultivation of crops in a crop rotation without fertilizers (especially without organic ones) will lead to soil degradation and lowering crop yields and arable land productivity to $1.2-1.5 \mathrm{t} / \mathrm{ha}$ of grain-units.

Therefore, for the reproduction of soil fertility and obtaining stably planned high yields, it is necessary to skillfully use local organic fertilizers (GCM, green manure, manure) in crop rotations.

\section{Conclusion}

Organic fertilizers reduce moisture loss from the soil surface and, as a result, its content throughout the growing season of crops is optimal and good. At the same time, in all soil layers from the background of direct effect and to the background of the second year of aftereffect, the amount of productive moisture increases dynamically, which is explained by a steady improvement in the structural-aggregate composition of the soil and the excellent water resistance of its granules. As a result, against the background of organic fertilizers, the accumulation and preservation of moisture is greater than against the backgrounds of mineral fertilizers and without fertilizers.

The content of nutrients (nitrogen, phosphorus and potassium) on the background of the effect and aftereffect of organic fertilizers significantly exceeds the background results without fertilizers and, in most cases, those of the background with the annual application of mineral fertilizers, calculated to receive 4 t/ha of grain and produce, similar in calorie value, from other crops

Under the direct effect of various GCM norms and their aftereffects of the first and second years, the productivity of the grain tillage sequence of the grain tillage crop rotation increased by $82-125 \%$ (6.07-9.26 t/ha of grain-units), and with the increased norms of GCM application the productivity of the crop rotation was increasing accordingly.

Due to the effect and aftereffect of $42 \mathrm{t} / \mathrm{ha}$ of strawbased manure (3 t/ha of GCM in composition), the productivity of the crop rotation link increased by $110.95 \%$, due to the effect and aftereffect of $27 \mathrm{t} / \mathrm{ha}$ of buckwheat green manure - by $79.32 \%$ relative to control (natural background).

In terms of action and aftereffects of $42 \mathrm{t} / \mathrm{ha}$, strawbased manure was almost equal to $3 \mathrm{t} / \mathrm{ha}$ of GCM and $27 \mathrm{t} / \mathrm{ha}$ of buckwheat green manure - to $1 \mathrm{t} / \mathrm{ha}$ of GKP.

With the application of various norms of GCM and buckwheat grean manure, taking into account their effect and aftereffect, the profitability of production increased by $83.9-157.42 \%$, and when $42 \mathrm{t} /$ ha of straw-based manure was applied ( $3 \mathrm{t} / \mathrm{ha}$ of GCM in composition) by $2.24 \%$ compared with the annual application of high doses of mineral fertilizers, calculated to receive $4 \mathrm{t} / \mathrm{ha}$ of grain-units.

\section{References}

1. P.A. Chekmarev, A.A. Lukmanov, I.D. Davletshin, et al., Directory of the Agrochemist of the Republic of Tatarstan (Kazan, 2015)

2. V.I. Fisinin, V.G. Sychev, V.A. Sedykh et al., The use of bird droppings in agriculture (NIKPTS Voskhod A, Moscow, 2013)

3. Richard Ansong Omari, Han Phyo Aung, Mudan Hou, Influence of different plant materials in combination with chicken manure on soil carbon and nitrogen contents and vegetable yield, PEDOSPHERE, 26(4), 510-521 (Published: AUG 2016)

4. V.P. Lysenko, Poultry farms are allies of farmers, Agricult., 5 (2014)

5. D.N. Prianishnikov, Selected Works, vol. 3 (Moscow, 1952)

6. D.N. Prianishnikov, Selected Works, vol. 1 (Moscow, 1965)

7. R.S. Shakirov, Earth fertility (Tatar Book Publishing House, Kazan, 1989) 